\title{
Physiological and genetic regulation of rRNA synthesis in Lactococcus
}

\author{
Thomas BERESFord $†$ and SÉAmus Condon* \\ Department of Food Microbiology and National Food Biotechnology Centre, University College, Cork, Ireland
}

(Received 23 December 1992; revised 5 March 1993; accepted 16 March 1993)

\begin{abstract}
The macromolecular composition of Lactococcus was regulated by growth rate in the same general way as that of less fastidious bacteria such as Escherichia coli and Salmonella typhimurium. The ratios of RNA:DNA and RNA:protein increased approximately threefold over a 13-5-fold increase in growth rate, whereas the ratio of DNA: protein remained approximately constant. Using reporter genes fused to a DNA fragment of a cloned lactococcal rRNA operon, promoter activity was located upstream of the 16S rRNA structural gene. This DNA fragment had some characteristics typical of a $r r n$ promoter in $E$. coli. Two consensus promoter sequences $P 1$ and $P 2$ were located 296 and $157 \mathrm{bp}$, respectively, upstream of the start of the 16S rRNA gene. Between P2 and the start of the 16S rRNA gene, sequences were identified with typical anti-termination motifs characteristic of $E$. coli rrn promoter regions. A putative transcription terminator sequence was identified downstream of the 5S rRNA gene and putative primary RNA transcript processing sites at both ends of the lactococcal rRNA operon were also noted.
\end{abstract}

\section{Introduction}

Lactic acid bacteria play a very important role in the preservation of dairy, meat and plant food products. In dairy products they are used primarily to convert lactose to lactic acid but in addition they contribute to the flavours characteristic of those products (Daly, 1983). With the development of molecular biology techniques a significant effort is being made, in several research laboratories, to understand the physiology and genetics of these industrially important bacteria. In the forefront of this work are studies on lactococci, formerly recognized as constituent members of the streptococci (Schleifer et al., 1985). Most of the initial genetic analyses have focussed on those traits associated with plasmids (de Vos, 1987), due both to their accessibility and the

\footnotetext{
*Author for correspondence. Tel. 21276871 ext. 2396; fax 21 275934 .

† Present address: New Zealand Dairy Research Institute, Private Bag, Palmerston North, New Zealand.

Abbreviations: Cm, chloramphenicol; CAT, chloramphenicol acetyltransferase; Em, erythromycin; $\mathrm{Tc}$, tetracycline.
}

The nucleotide sequences of the 16S RNA gene promoter region and the 5S RNA gene region have been assigned EMBL accession numbers $\mathrm{X} 65713$ and $\mathrm{X} 65712$, respectively. industrially important traits which they encode. However, if greater practical manipulation of these bacteria is to be achieved, a more complete understanding of their physiology and growth regulatory mechanisms must be obtained. In this context we have initiated work on macromolecular changes in cell composition affected by growth rate of lactococci.

Compared to Escherichia coli, lactococci have a greatly curtailed biosynthetic ability. Unlike $E$. coli the growth of lactococci is not possible in a glucose-ammonia-salts medium as several amino acids and vitamins are essential nutrients. Furthermore, in environments such as milk, growth of lactococci is dependent on their abilities to hydrolyse proteins and peptides (Reiter \& Oram, 1962; Marshall \& Law, 1984). We decided to examine if the models generally accepted for growth-rate-associated changes in cell macromolecular composition established with enteric bacteria can be confidently applied to the much more fastidious lactococci.

According to these models bacteria adjust their macromolecular composition according to nutritionimposed growth rate; as the growth rate increases the cell biomass becomes richer in ribosomes and slightly poorer in protein and DNA. These changes allow the cells to grow at the maximum rate that the particular medium is capable of supporting (Schaechter et al., 1958). The increase in ribosome content is due to increased transcription of rRNA operons and an increase in

0001-8048 C 1993 SGM 
Table 1. Bacterial strains and plasmids used in this study

\begin{tabular}{|c|c|c|}
\hline Strain or plasmid & Relevant feature & Reference \\
\hline $\begin{array}{l}\text { L. lactis subsp. lactis } \\
\text { NCDO } 712\end{array}$ & Parent strain & Gasson (1983) \\
\hline $\begin{array}{l}\text { L. lactis subsp. lactis } \\
\text { MG1363 }\end{array}$ & Plasmid-free strain of NCDO 712 & Gasson (1983) \\
\hline E. coli $\mathrm{HB} 101$ & Transformation strain & Maniatis et al. (1982) \\
\hline рТВ201 & Lactococcal $r m$ genes in pACYC184 & $\begin{array}{l}\text { Beresford \& Condon } \\
\text { (1991) }\end{array}$ \\
\hline pMP220 & $\mathrm{Tc}^{\mathrm{R}}$, promoterless $\operatorname{lac} Z$ gene & Spaink et al. (1987) \\
\hline pGKV210 & $\mathrm{Em}^{\mathrm{R}}$, promoterless $\mathrm{Cm}^{\mathrm{R}}$ gene & $\begin{array}{l}\text { Van der Vossen \& } \\
\text { Venema }(1985)\end{array}$ \\
\hline pTB301 & $\begin{array}{l}\text { pMP220 containing } L \text {. lactis subsp. lactis } \\
\text { tRNA promoter region }\end{array}$ & This study \\
\hline pTB401 & $\begin{array}{l}\text { pGKV210 containing } L \text {. lactis subsp. lactis } \\
\text { rRNA promoter region }\end{array}$ & This study \\
\hline
\end{tabular}

ribosomal protein synthesis due mainly to an increased rate of translation of mRNA from ribosomal (r-) protein/protein mRNA (Bremer \& Dennis, 1987; JinksRobertson \& Nomura, 1987). E. coli has seven rrn operons (Ellwood \& Nomura, 1982) with approximately the same organization: tandem promoters $\mathrm{Pl}$ and P2-16S-spacer-23S-5S genes-terminator region (JinksRobertson \& Nomura, 1987). Each promoter region is subject to at least three control systems. In the first, $r r$ expression from Pl is regulated by the growth rate (Nomura et al., 1984). The second, known as the stringent response (Stent \& Brenner, 1961) is characterized by the inhibition of expression from $\mathrm{P} 1$, on cessation of protein synthesis, indicated by the absence of charged amino acyl tRNA (Cashel \& Rudd, 1987). The third control is characterized by a stimulation of $r r n$ expression from $\mathrm{P} 1$ following binding of a protein known as the Fis protein to regions upstream of P1 (Ross et al., 1990). It is thought that expression from $r r n \mathrm{P} 2$ is constitutive and designed to ensure a continuance of a low level of expression when expression from $r r n$ P1 is blocked (Sarmientos \& Cashel, 1983). In addition expression of E. coli rrn operons is affected by antitermination sequences located between $\mathrm{P} 2$ and the $16 \mathrm{~S}$ rRNA structural gene. These sequences are similar to nut anti-termination sequences of bacteriophage $\lambda$ (Gourse et al., 1986; Berg et al., 1989).

This report is concerned with measurement of RNA, DNA and protein of a lactococcal strain growing over a wide range of growth rates and examination of a recently cloned lactococcal $\mathrm{rrn}$ operon (Beresford \& Condon, 1991) for transcription regulation sequences.

\section{Methods}

Bacteria strains and plasmids. Bacterial strains and plasmids used in this study are listed in Table 1.
Growth and macromolecular composition. E coli strains were routinely grown and maintained in LB medium (Maniatis et al., 1982) with antibiotics as appropriate. The concentrations were as follows: tetracycline (Tc), $10 \mu \mathrm{g} \mathrm{ml}^{-1}$; ampicillin (Ap), $25 \mu \mathrm{g} \mathrm{ml}^{-1}$; and erythromycin $(\mathrm{Em}), 500 \mu \mathrm{g} \mathrm{ml}^{-1}$. When required, $\mathrm{X}$-gal was added at $50 \mu \mathrm{g} \mathrm{ml}^{-1}$. L. lactis subsp. lactis strains were grown routinely on M17 medium (Terzaghi \& Sandine, 1975) with glucose as the carbon source (GM17). Em was added at $5 \mu \mathrm{g} \mathrm{ml}^{-1}$ and chloramphenicol (Cm) was used as indicated.

Growth of L. lactis subsp. lactis NCDO 712 in batch cultures for assay of growth rate and macromolecular composition was in either Thomas et al. (1979) chemically defined medium (TEL) or in modifications of this medium. Modified TEL (MTEL) contained the amino acids; Arg, Cys, Glu, His, Ile, Leu, Lys, Met, Phe, Pro and Val at the concentrations present in TEL. MTEL $+\mathrm{T}$ and MTEL + YE were made by adding tryptone or yeast extract, respectively, to MTEL at $0.5 \%(\mathrm{w} / \mathrm{v})$. All batch cultures were incubated at $30^{\circ} \mathrm{C}$ without aeration. Growth was monitored as $\mathrm{OD}_{600}$ on a Phillips model Pye Unicam PU8600 UV/Vis spectrophotometer. The growth rate $\left(k, \mathbf{h}^{-1}\right)$ of batch cultures was calculated from semi-log graphs of ${ } D_{600}$ against time using the formula:

$$
k=\ln X_{2}-\ln X_{1} / t_{2}-t_{1}
$$

where $X_{2}$ and $X_{1}$ were exponential phase $\mathrm{OD}_{600}$ values of the cultures at times $t_{2}$ and $t_{1}$, respectively.

In continuous chemostat cultures TYG medium containing tryptone $\left(17 \mathrm{~g} \mathrm{l}^{-1}\right)$, yeast extract $\left(3 \mathrm{~g} \mathrm{l}^{-1}\right)$ glucose $\left(5 \mathrm{~g} \mathrm{l}^{-1}\right), \mathrm{Na}_{2} \mathrm{HPO}_{4}\left(2.28 \mathrm{~g} \mathrm{l}^{-1}\right.$, $\mathrm{KH}_{2} \mathrm{PO}_{4}\left(3.27 \mathrm{~g} \mathrm{l}^{-1}\right.$ ) was used in a BioFlo chemostat (New Brunswick Scientific). Cultures were incubated at $30^{\circ} \mathrm{C}$ under a head of nitrogen and were agitated at 200 r.p.m. The $\mathrm{pH}$ in the fermenter vessel was maintained at approximately $6.7(6.52-6.82)$ by continuous addition of $4 \mathrm{M}-\mathrm{NaOH}$.

Biochemical assay of macromolecular composition was as follows. Protein was extracted from cells in $1 \mathrm{M}-\mathrm{NaOH}$ at $90^{\circ} \mathrm{C}$ for $10 \mathrm{~min}$ and measured by the Lowry method. Bovine serum albumin was used as a standard. RNA was measured by the orcinol method as described by Griswold et al. (1951) with ribose as the standard. Total cellular DNA was assayed by the method of Burton (1957) with herring sperm DNA, degraded free acid, as the standard.

DNA manipulations. Plasmid DNA was isolated from E. coli by the method of Birnboim \& Doly (1979). Plasmid DNA was extracted from L. lactis subsp. lactis by the method of Anderson \& McKay (1983). DNA required for cloning and sequencing was further purified by $\mathrm{CsCl}$ 
gradient density centrifugation (Maniatis et al., 1982). Endonuclease enzymes, alkaline phosphatase and DNA ligase were obtained from Boehringer Mannheim and were used according to the manufacturer's instructions. Transformation of E. coli was according to Mandel \& Higa (1970). Electroporation of $L$. lactis subsp. lactis was achieved by the method of Holo \& Nes (1989).

The nucleotide sequence of the promoter region and the $3^{\prime}$ end of the $r m$ operon was determined in both directions by the chain termination method of Sanger et al. (1977) with a T7 polymerase sequencing kit obtained from Promega and $\left[\alpha-{ }^{35}\right.$ S $]$ ATP from Amersham. Sequencing templates were alkali-denatured double-stranded DNA pTB201 molecules (Beresford \& Condon, 1991).

Cloning of a putative lactococcal rrn promoter. The starting material was a plasmid pTB20l containing a complete lactococcal $r r n$ operon on a $5.4 \mathrm{~kb}$ DNA fragment. The $r r n$ operon contained a $1.4 \mathrm{~kb} E c o \mathrm{RI}$ fragment which included part of the 16S RNA structural gene $(0.6 \mathrm{~kb})$ and the region $(0.8 \mathrm{~kb})$ immediately upstream. The $1.4 \mathrm{~kb} \mathrm{E}$. coli fragment was fused to a promoterless $l a c Z$ gene of the promoter probe vector pMP220 and transformed into $E$. coli $\mathrm{HB} 101$. A number of transformants were selected using X-gal as an indicator and checked to confirm the presence of $1.4 \mathrm{~kb}$ inserts in the original (pTB201) orientation. One of these clones, pTB301, was selected for further study.

Since pTB301 does not replicate in lactococci the $1.4 \mathrm{~kb}$ lactococcal DNA insert from pTB301 was cloned as a $B g l / \mathrm{H} / P_{s t} \mathrm{I}$ fragment into the shuttle promoter probe vector pGKV210. This vector has a promoterless $\mathrm{Cm}$ acetyltransferase (CAT) gene and a selectable Em resistance $\left(\mathrm{Em}^{\mathrm{R}}\right)$ gene. The ligation mix was transformed into $E$. coli HB101 and plated on LB with Cm and Em. One resultant clone, pTB 401 , was analysed to confirm the presence of the $1.4 \mathrm{~kb}$ lactococcal insert in its original (pTB201) orientation.

Promoter activity. $\beta$-Galactosidase activity was measured according to the method of Miller (1972). CAT activity was determined by the method of Shaw (1975). Minimal inhibitory concentrations of chloramphenicol on L. lactis subsp. lactis strains were determined in GM17 medium after overnight incubation at $30^{\circ} \mathrm{C}$.

\section{Results}

\section{Effect of growth rate on the RNA,DNA and protein composition of L. lactis}

Two approaches were taken to determine whether $L$. lactis NCDO 712 varied its macromolecular composition according to its rate of growth. The first approach was to measure RNA, DNA and protein in exponentially growing batch cultures. To vary the growth rate the composition of the growth medium was varied. The chemically defined TEL medium contains 20 amino acids. A modified version of this medium (MTEL) was devised based on a previous report (Reiter \& Oram, 1962), which indicated that all 20 amino acids were not required for growth of NCDO 712. MTEL contained 11 amino acids. Two further modifications of MTEL were made; one was MTEL plus tryptone $(+\mathrm{T})$ and the other MTEL plus yeast extract (+YE). L. lactis NCDO 712 grew 4.9-times faster in MTEL + YE, the medium supporting the fastest growth rate, than in MTEL which supported the slowest growth rate. The DNA:protein ratio remained relatively constant over this range of growth rate. However, the RNA content was growthrate-dependent; the RNA: protein and the RNA:DNA ratios increased by factors of 1.9 and $2 \cdot 2$, respectively, as the growth rate increased 4.9 -fold.

The second approach to varying the growth rate was to vary the availability of the energy source by growing the cultures in a chemostat at different dilution rates. The chemostat was operated with a complex medium, TYG, in which glucose was limiting and the growth rate was altered by changing the flow rate of the incoming medium. In this manner a $6 \cdot 25$-fold variation in growth rate was obtained. Under these growth conditions the DNA:protein ratio again remained constant. The RNA: protein ratio increased 1.76 -fold over this range of growth rates and the RNA:DNA ratio varied by $1.73-$ fold.

Combining both sets of data indicates that there is an approximately linear relationship between the specific growth rate and the RNA:protein and RNA:DNA ratios of $L$. lactis subsp. lactis NCDO 712 cells, over the range of growth rates monitored (Fig. $1 a$ and $b$, respectively). A 13.5-fold range in specific growth rate was achieved, over which RNA:protein varied 2.5-fold and RNA:DNA varied 3.1-fold. A positive intercept was
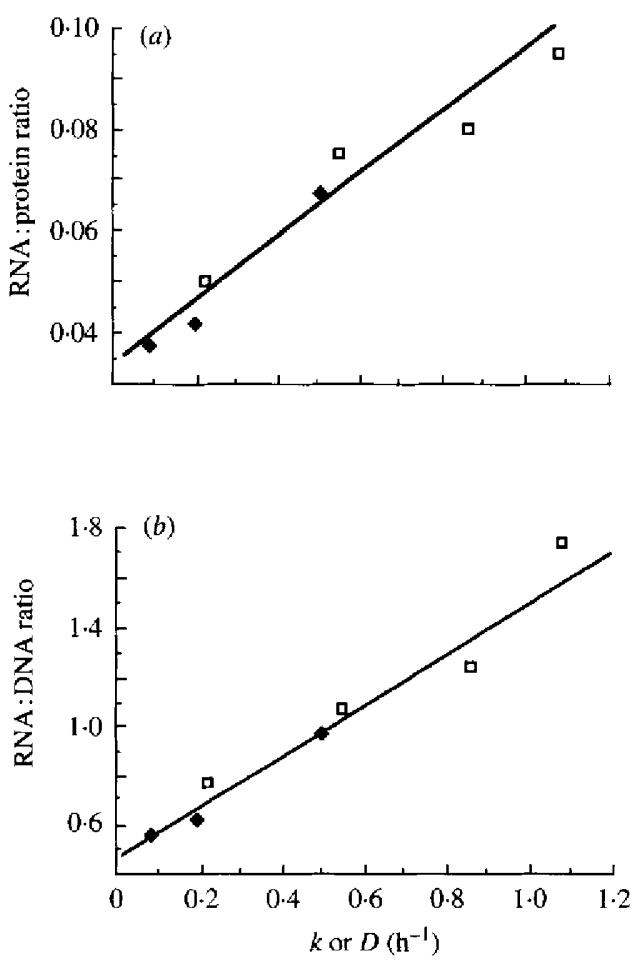

Fig. 1. (a) Graph showing the relationship between the growth rate $[k$ (see Methods) or $D$ (dilution rate)] and the ratio of RNA:protein, measured in both batch $(\square)$ and chemostat $(\bullet)$ cultures. (b) Graph showing the relationship between the growth rate and the ratio of RNA: DNA, measured in both batch $(\square)$ and chemostat $(\bullet)$ cultures. 
noted on the ordinate of both graphs indicating a minimum stable RNA content at zero growth rate. These data indicate that the stable RNA content of the lactococcal cell is regulated by growth rate.

\section{Identification of promoter activity associated with the $5^{\prime}$ end of the rrn operon}

The correlation of RNA content with growth rate suggested that expression of $r r n$ operons in lactococci responds to growth rate stimulation and that promoters of $r r n$ operons might have some structural features similar to those identified in $E$. coli. In a previous paper (Beresford \& Condon, 1991) the genes for one of the rRNA operons of NCDO 712 were cloned on a plasmid, pTB201, which contains $5.4 \mathrm{~kb}$ of the lactococcal chromosome. The start of the 16S rRNA gene was identified on a $1.4 \mathrm{~kb} E c o$ RI fragment which also contained $0.8 \mathrm{~kb}$ of DNA upstream of the structural $16 \mathrm{~S}$ rRNA gene. This $0.8 \mathrm{~kb}$ was a likely location for the promoter of the rRNA operon. To test for promoter activity, the $1.4 \mathrm{~kb} E c o$ RI fragment of pTB201 was fused to a promoterless $l a c Z$ gene of a promoter probe vector, pMP220. One of the resultant constructs, pTB301, was assayed for promoter activity by assaying $\beta$-galactosidase activity in exponential phase $E$. coli $\mathrm{HB} 101$ cells. The lactococcal insert in pTB301 caused a 300-fold increase in $\beta$-galactosidase activity, compared to that in cells containing the vector pMP220 alone. This confirmed that even in a heterologous host, substantial promoter activity was associated with the $1.4 \mathrm{~kb} E c o$ RI fragment of pTB201.

The plasmid pTB301 was unable to replicate in $L$. lactis subsp. lactis. To prove that the promoter activity noted in $E$. coli was also present in a lactococcal background, the insert from pTB301 was cloned into the shuttle promoter probe vector pGKV210 which has a promoterless CAT $\left(\mathrm{Cm}^{\mathrm{R}}\right)$ gene. A resultant plasmid, pTB401, was transformed by electroporation into $L$. lactis subsp. lactis MG1363 to determine if the lactococcal insert was capable of promoting the expression of the CAT gene in its homologous background. Transformants were initially selected on GM17 with Em $\left(5 \mu \mathrm{g} \mathrm{ml}^{-1}\right)$ and clones were then spotted onto GM17 plates containing $\mathrm{Em}\left(5 \mu \mathrm{g} \mathrm{ml}^{-1}\right)$ with a $\mathrm{Cm}$ concentration of $1-4 \mu \mathrm{g} \mathrm{m}^{-1}$. Controls of L. lactis subsp. lactis MG1363 containing the plasmid pGKV210 were also spotted onto the plates. All clones containing pTB401 were able to grow in the presence of $\mathrm{Cm}$ at $4 \mu \mathrm{g} \mathrm{ml}^{-1}$, whereas the controls were not. The ability of pTB401 to promote expression of the CAT gene was measured by assaying the biomass generated after $24 \mathrm{~h}$ growth in GM17 broth containing increasing amounts of $\mathrm{Cm}$. The results (Fig. 2) indicate that strains carrying the vector

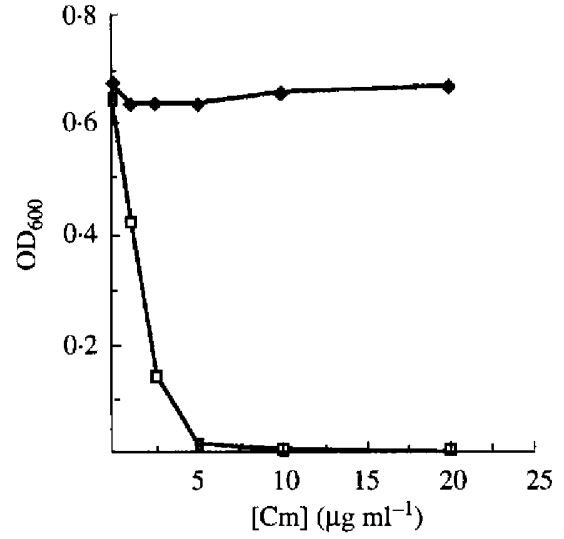

Fig. 2. Growth measured by $\mathrm{OD}_{600}$ after $24 \mathrm{~h}$ at $30^{\circ} \mathrm{C}$ in $\mathrm{GM} 17$ medium with various concentrations of $\mathrm{Cm}$, of L. lactis MG1363 with either pGKV210 ( $\square$ ) or its derivative pTB401 ( ). pGKV210 has a promoterless CAT gene; pTB401 has $1.4 \mathrm{~kb}$ of the $5^{\prime}$ side of the $r r n$ operon from NCDO 712 fused to the CAT gene of pGKV210.

alone were very sensitive to $\mathrm{Cm}$ and did not grow well at concentrations greater than $2 \mu \mathrm{g} \mathrm{ml}^{-1}$, whereas those carrying pTB401 grew well in the presence of at least $25 \mu \mathrm{g} \mathrm{Cm} \mathrm{ml}{ }^{-1}$. This confirms that the $1.4 \mathrm{~kb} \mathrm{EcoRI}$ fragment contains DNA with strong promoter activity when expressed in L. lactis subsp. lactis.

\section{DNA sequence analysis of the putative rrn promoter region of L. lactis}

The base sequence of the $r n$ promoter region of $L$. lactis NCDO 712 was determined. The starting material was pTB201 which has a full $r r n$ operon and about $0.8 \mathrm{~kb}$ DNA upstream of the start of the structural genes. The $5^{\prime}$ end of the sequence was initiated from an oligonucleotide primer complementary to a known vector sequence just outside the insert DNA and the $3^{\prime}$ end was generated from an oligonucleotide complementary to a conserved region (Collins et al., 1989) about $100 \mathrm{bp}$ downstream of the 16S rRNA sequence start point. The DNA sequenced is 833 bp long (Fig. 3) and its GC content is $35.4 \%$, which is within the range expected for lactococcal DNA (Stackebrandt \& Teuber, 1988). The sequence included 25 bp corresponding to the $5^{\prime}$ end of the 16S rRNA sequence as determined by alignment to $E$. coli (Brosius et al., 1981) and 16S rRNA sequences from other lactococci (Collins et al., 1989). An EcoRI site was located at the extreme $5^{\prime}$ end of the insert and $X h o \mathrm{I}$ and HindIII sites were located internally. The $X h o \mathrm{I}$ site was $452 \mathrm{bp}$ downstream of the EcoRI site and the $H$ indIII was a further $80 \mathrm{bp}$ downstream. These locations for the restriction sites were in good agreement with earlier data, determined by restriction analysis (Beresford \& Condon, 1991). 
$\mathrm{E}$

GAATTCGAAGGTTTAITTTCTGGAATGAAACCAATCATCAGAAAATTTGATGARACAAATT

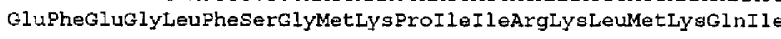

CGAATCAAAGCATGGGACATAGAGGATTATTATCAAGAAGGAATGATTATTTTGCAMCAC Arg I leLy sAla TrpAspI leGluAspTyrTYrGl nGluGlyMet Ile I leLeuH is His

CTTTTAGAAGAAAATCACCCATCCACTAATATTTATACAAAGTTCAAAGTAZAATATCAT LeuLeuGluGluAsnHisProSerThrAsnIleTyrThrLys PheLysVal LysTyrHis

CAACATTTGATTEATGAACTACGCCATAGCTACGCCAAAAAACGOCTTCATGACCATTTT GinHisLeuI leAspGluLeuArgH is SerTyrAlaLy SysArgLeuH isAspH is Phe

GTAGGTCTGGACATTTATGAATGTMCGGACTGGATAGATGCAGGAGGAGTACCCCTGA ValGlyLeuAsp I I TyrGluCysSerAspTrpI leAspAlaGlyGlySerThrProGlu

AGCGAGCTTGTGTTCAATCATCTTTTAGCAGAAGTTTATGAAGGATTGAGCGCCCACTAT SerGluZeuVal PheAsnH isLeıLeuAlaGluVa 1TyrGluGlyLeuSerAlaHistyr

CAGGAATTACTCGTGCGTCAAATGAGAGGAGAAGAACTCACGCGAATGGAACGCTATCG GInGluLeuLeuValArgGlnMetArgGlyGluGluLeuThrArgMetGluArg'Yyrarg

$\mathrm{X}$ 480

CTAAGAGAAAAAATCAAAATATACTATTTTCTCGAGATGATGATTAAAAAAAGCTCCCT LeuArgGluLYsIleLYsAsnIl eLeuPheSerArgAspAspAsp

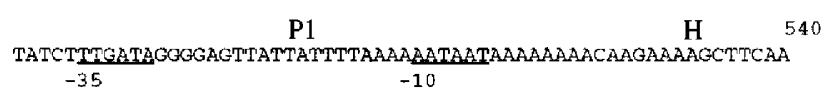

600

GCGTTTGCTAGCCTAAGTTAAAACGGATACATAAGTAGATTAAAACGAACAAAAGGGGAA

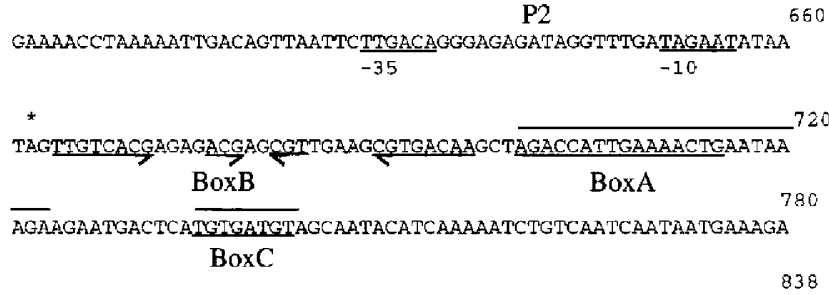

CAAGCCAGTCACTTCGGTGACTTAAATACTTTAtttgagagttg gatcotggcteago

Fig. 3. Sequence of the entire promoter region from the L. lactis subsp. lactis rRNA operon. The upstream open reading frame is indicated with the derived amino acid sequence. Restriction sites are denoted by: E, EcoRI; X, XhoI, H, HindIII. The -10 and -35 sites of the two putative promoters $\mathrm{P} 1$ and $\mathrm{P} 2$ are underlined. The BoxB antitermination region is highlighted by arrows. BoxA and $\mathrm{C}$ motifs are denoted by over- and underlining. The probable transcriptional start point of P2 as determined by Van der Vossen et al. (1985) is indicated by $*$. The putative processing site is indicated by the overline which partially overlaps BoxA. The $5^{\prime}$ end of the mature $16 \mathrm{~S}$ rRNA, as determined by sequence alignment to reported $16 \mathrm{~S}$ rRNA sequences (Brosius et al., 1981; Collins et al., 1989), is shown in lower case italicized lettering.

Extending downstream from the $E c o$ RI site there is an open reading frame which encodes part of a protein of 155 amino acids. No significant homology was observed between the amino acid sequence and those previously stored in the databanks. No attempt was made to determine whether or not this protein is synthesized in vivo.

By comparison with published lactococcal promoter sequences (see Discussion) two putative tandem

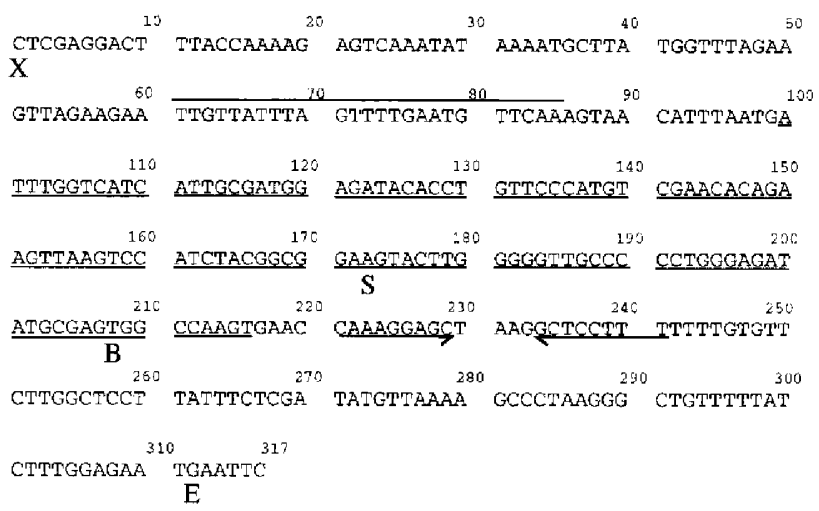

Fig. 4. Sequence of the $X$ hol $/ E c o$ RI fragment of pTB201. The sequence of the 5S rRNA gene is underlined. The $5^{\prime}$ and $3^{\prime}$ ends of the $5 \mathrm{~S}$ rRNA gene were determined by sequence comparison to that obtained for $L$. lactis subsp. cremoris (Neimark et al., 1983). The positions of restriction sites are indicated by: X, XhoI; S, SacI; B, BalI; E, EcoRI. The arrows indicate the inverted repeat putative transcription termination sequences. A putative primary processing site is indicated by an overline.

promoters were identified 296 and $157 \mathrm{bp}$ from the $5^{\prime}$ start of the mature 16S rRNA sequence. These were designated P1 and P2 (Fig. 3), consistent with the notation used for E. coli rrn promoters (Young \& Steitz, 1979). Sequences with characteristics of anti-termination motifs in $E$. coli (see Discussion) were located between P2 and the start of the 16S rRNA gene.

\section{Putative rrn operon termination}

Previous work established that the plasmid pTB201 contained the structural genes for the $16 \mathrm{~S}$ and $23 \mathrm{~S}$ rRNAs and that both genes were tightly linked (Beresford \& Condon, 1991). A small 0.3 kb XhoI/EcoRI DNA fragment adjacent to the $3^{\prime}$ end of the $23 \mathrm{~S}$ rRNA gene was also identified in that work. The complete nucleotide sequence of the $X h o l / E c o$ RI fragment was obtained and by comparison with a previously determined L. lactis subsp. cremoris sequence (Neimark et al., 1983), this region was shown to encode a 5S rRNA gene of $117 \mathrm{bp}$. Examination of the sequence region immediately downstream of the 5S rRNA gene revealed a putative transcription terminator, a perfect inverted repeat sequence which forms an 8 bp stem with an unpaired 4 base loop followed by a sequence rich in $T$ residues (Fig. 4).

\section{Identification of putative $r R N A$ processing sites}

On the basis of comparison with other Gram-positive bacteria (see Discussion) two putative processing sites have been identified in the $r r n$ operon of L. lactis NCDO 
712. The first overlaps the BoxA region between $\mathrm{P} 2$ and the 16S rRNA sequence (Fig. 3) and the second which is complementary to the first is located in the spacer region between the 23S and the 5S rRNA genes (Fig. 4).

\section{Discussion}

In both batch and continuous chemostat cultures of $L$. lactis NCDO 712 an increase in the growth rate correlated to an increased RNA content of biomass relative to either protein or DNA. Above a threshold value, corresponding to the macromolecular composition at zero growth rate, the RNA content increased directly in proportion to growth rate increases (Fig. 1). Since the rate of increase of RNA with growth rate was the same in batch cultures, where the energy source was in excess, and in chemostat cultures, where the energy source was limiting (Fig. 1), it is unlikely that the RNA content is controlled by the nutritional status of the medium. It is more likely that the RNA content is regulated by the growth rate per se, as has been observed with enteric bacteria and other microbes (Nierlich, 1978).

The RNA measured here is stable RNA which consists mainly of rRNA. In an earlier report (Beresford \& Condon, 1991) we showed that the L. lactis NCDO 712 genome has six sets of rRNA genes. One set was cloned and was found to be organized in a manner similar to that in E. coli, in that genes for $16 \mathrm{~S}, 23 \mathrm{~S}$ and 5S RNA were closely linked within a DNA fragment of approximately $5.4 \mathrm{~kb}$. The start of the $16 \mathrm{~S}$ rRNA gene resided about $0.8 \mathrm{~kb}$ inside the $5^{\prime}$ edge of the cloned fragment. This $0.8 \mathrm{~kb}$ piece was an ideal sequence in which to search for regulatory sites.

The nucleotide sequence revealed an organization similar in outline to that in E. coli. First, two tandem promoter-like sequences, P1 and P2, were identified, 296 and $157 \mathrm{bp}$ upstream of the 16S rRNA gene (Fig. 3), respectively. The distal putative promoter, $\mathrm{P} 1$, has both -10 and -35 sites that conform well to the lactococcal consensus sequences. Five of the six nucleotides in the -35 motif ( $5^{\prime}$ TTGATA $3^{\prime}$ ) are present in the consensus sequence $\left(5^{\prime}\right.$ TTGACA $\left.3^{\prime}\right)$. In his review, de Vos (1987) noted that the $\mathrm{C}$ at position 5 was conserved in only five of ten Lactococcus promoters examined, whilst a $\mathrm{T}$ was present in three of the remainder. Five of the six consensus nucleotides ( $5^{\prime}$ TATAAT $\left.3^{\prime}\right)$ are again present in the -10 sites $\left(5^{\prime}\right.$ AATAAT $\left.3^{\prime}\right)$. The $5^{\prime} \mathrm{T}$ is a highly conserved nucleotide, occurring in nine of the ten promoters examined. However, the exception also has an $\mathrm{A}$ in this position (de Vos, 1987). The $20 \mathrm{bp}$ spacing between the putative -10 and -35 sites is bigger than the normal spacing, which is 15-18 bp (de Vos, 1987). However, Koivula et al. (1991) have also identified promoters in L. lactis subsp. lactis which have unusual lengths between their -10 and -35 sites; one of the promoters which they characterized had a $20 \mathrm{bp}$ sequence between the two sites. The large distance between the -10 and -35 sites suggests that P1 may be a weak promoter. However, between -35 and -80 the sequence is $71 \%$ AT compared to the genomic average of $61 \%$ (Stackebrandt \& Teuber, 1988); this is characteristic of very active promoters. AT-rich DNA can form unusual secondary structures referred to as bent DNA, which is thought to be involved in elevated rates of expression of promoters containing it (Gourse et al., 1986). This may compensate for any reduced activity associated with the large spacing between the -10 and -35 sites. Occupying the first and fourth positions downstream of the -10 sequence, two adenine residues are located which is also characteristic of lactococcal promoters.

The -35 motif of the $\mathrm{P} 2$ promoter conforms perfectly to the proposed lactococcal canonical sequence. The -10 motif (TAGAAT) has one mismatch in the $6 \mathrm{bp}$ sequence. In the ten promoters examined by de Vos (1987) only one had a G located at position 3; it is a variable site, however, with only four of the promoters examined conforming to the consensus at this site. The distance between the -10 and -35 sites was $17 \mathrm{bp}$ which is typical of lactococcal promoters (de Vos, 1987) and again an AT-rich region was identified immediately upstream of the -35 region.

Comparison of the sequences within and downstream of the P2 promoter indicated that it was highly homologous to promoter P59, one of several promoters identified by Van der Vossen et al. (1985) who used a promoter probe vector to clone promoter fragments from a $L$. lactis subsp. cremoris strain. In the $98 \mathrm{bp}$ downstream of the -35 site of $\mathrm{P} 2$, only three mismatches were noted with P59. In the first $19 \mathrm{bp}$ upstream from the -35 site in these two promoters the sequence identity was also good at $84 \%$ but then it dropped off rapidly. Anti-termination BoxB and BoxA motifs are also evident in the P59 sequence. This evidence supports the suggestion that P59 is an rRNA promoter from L. lactis subsp. cremoris. Van der Vossen et al. (1985) identified the transcriptional start of promoter P59. As the sequence of the L. lactis subsp. lactis $\mathrm{rRNA}$ promoter reported here is identical to P59 in this region, the transcriptional start of the L. lactis subsp. lactis rRNA P2 promoter is probably the A at position 662 (Fig. 3).

A second major similarity in organization between E. coli $r r n$ promoter regions and the lactococcal DNA upstream of the 16S rRNA gene concerns anti-termination sequences. Uncoupling of translation from transcription in bacteria leads to premature termination of transcription (Adhya \& Gottesman, 1978). This potential problem for transcription of $r r n$ operons is avoided by the presence of anti-termination sequences 
which permit readthrough of $r m$ structural genes by RNA polymerase. Anti-termination sequences in $E$. coli consist of three sequence motifs known as BoxA, B and $\mathrm{C}$ which are very similar to bacteriophage $\lambda$ antitermination sequences. BoxB is a region of hyphenated dyad symmetry whereas BoxA and BoxC are specific sequences (Berg et al., 1989). Sequence motifs similar to those of BoxA, B and C of E. coli rrn promoter regions were identified in the lactococcal $r r n$ promoter region (Fig. 3). Furthermore the location and orientation of the three motifs between P2 and the start of the 16S rRNA gene was similar in both organisms. Putative antitermination sequences have been identified in the promoter regions of $r r n$ operons in many bacteria besides E. coli (Berg et al., 1989). Similar motifs have also been noted in the spacer regions between $16 \mathrm{~S}$ and 23S rRNA genes. The BoxA sequences were found either abutting or within the primary transcript processing sites (Pernodet et al., 1989; Berg et al., 1989).

The circumstantial evidence obtained by sequence analysis and comparison, that the sequence upstream of the 16S rRNA gene should be capable of promoter activity was corroborated from studies with fusions of the relevant lactococcal DNA fragment with promoterless reporter genes. A $1.4 \mathrm{~kb}$ fragment consisting of the first $600 \mathrm{~kb}$ of the $16 \mathrm{~S}$ rRNA gene together with the $0.8 \mathrm{~kb}$ immediately upstream, promoted expression of the lac $Z$ gene in $E$. coli and the CAT gene in E. coli and L. lactis. No effect of growth rate on the expression of the lac $Z$ gene from the fusion plasmid in $E$. coli was noted (data not shown) but a growth rate effect was observed on expression of CAT activity in L. lactis. Expression of CAT activity from pTB401 in L. lactis MG1363 increased approximately twofold for a $33 \%$ increase in growth rate (data not shown). This could be explained if the copy number of pTB401 was greater in the faster growing cells but no appreciable difference in plasmid content between the two cultures was noted. Although the evidence is insufficient, the positive response to growth rate is encouraging and worthy of further experimentation.

The sequence of the region on the $3^{\prime}$ side of the $23 \mathrm{~S}$ gene indicates that it contains a typical 5S RNA gene sequence (Fig. 4) which is identical to a published sequence from L. lactis subsp. cremoris (Neimark et al., 1983) except that the latter has a $T$ in the first position instead of an A in the NCDO 712 gene. The $117 \mathrm{bp}$ length of the 5S rRNA is the expected length for a Grampositive eubacterium (Hori \& Osawa, 1979). Unlike $E$. coli rrn operons, typical tRNA sequences were not noted in the $101 \mathrm{bp}$ downstream nor in the $99 \mathrm{bp}$ upstream of the 5S rRNA gene.

Just 5 bases after the $3^{\prime}$ end of the 5 S rRNA gene sequence there is a perfect inverted repeat sequence which forms a structure typical of $\rho$-independent transcriptional terminators and is in the right position to terminate a complete transcript of the $r m$ operon (Young, 1979).

The $16 \mathrm{~S}, 23 \mathrm{~S}$ and $5 \mathrm{~S}$ rRNAs are formed by processing of the primary transcript (Birenbaum et al., 1978; King \& Schlesinger, 1987). The primary (RNase III) processing sites are located in sequences on either side of the $16 \mathrm{~S}$ and $23 \mathrm{~S}$ rRNAs; these sequences form double-stranded stalks with the $16 \mathrm{~S}$ and $23 \mathrm{~S}$ rRNAs as extensive loops (King \& Schlesinger, 1987). Pernodet et al. (1989) demonstrated a remarkable degree of conservation in 21 base sequences associated with primary processing sites of Grampositive bacteria; furthermore these sites shared extensive homology with BoxA anti-termination sequences of $E$. coli. By comparison with the Pernodet et al. (1989) sequences two putative processing sites have been identified in the L. lactis NCDO $712 \mathrm{rrn}$ operon. The first, which includes the putative BoxA sequence is located in the leader sequence between the 16S rRNA gene (Fig. 3). The lactococcal sequence shares 12 of 14 highly conserved bases with other Gram-positive processing sequences. A second sequence was identified in the 23S-5S rRNA spacer region (Fig. 4) which is highly complementary to the $16 \mathrm{~S}$ rRNA leader sequence. This is the likely processing site expected at the $3^{\prime}$ side of the 23S rRNA gene according to the current model for primary transcript processing.

In conclusion, the observations made in this report indicate that rRNA synthesis in Lactococcus is regulated according to the classic model generated from work mainly with E. coli. Previously (Beresford \& Condon, 1991) we showed that Lactococcus has six $r r n$ operons compared to seven in E. coli (Ellwood \& Nomura, 1982) and that the lactococcal $r m$ operons conformed to the classical 16S-23S-5S rRNA structural gene sequence. In the present study we have shown that the sequence upstream of the $16 \mathrm{~S}$ rRNA gene has several characteristics of the model $r r n$ promoter region such as tandem consensus promoter sequences and putative antitermination sequences. Furthermore, this putative lactococcal promoter turns on promoterless reporter genes in both homologous and heterologous hosts.

The classic correlation between RNA content of cell biomass and growth rate is evident in lactococcal cultures. We have very preliminary data which suggests that the cloned putative promoter may respond to growth rate stimulation. We have not yet looked for evidence of a stringent response or of a response similar to the Fis protein stimulation observed in E. coli (Ross et al. 1990). Finally, according to the classic model a $\rho$ independent terminator should exist at the end of the $5 \mathrm{~S}$ RNA structural gene (Young, 1979) and RNase III processing sites should be located at either side of the $16 \mathrm{~S}$ 
and 23S RNA transcripts (Birenbaum et al., 1978). We have noted characteristic sequences which indicate that termination and processing of rRNA transcripts in lactococci are in accord with the classic model.

\section{References}

AdHYa, S. \& GotTesman, M. (1978). Control of transcription termination. Annual Reviews of Biochemistry 47, 967-996.

ANDERSON, D. G. \& MCKAY, L. L. (1983). A simple and rapid method for isolating large plasmid DNA from lactic streptococci. Applied and Environmental Microbiology 46, 549-552.

Beresford, T. \& Condon, S. (1991). Cloning and partial characterisation of genes for ribosomal ribonucleic acid in Lactococcus lactis subsp. lactis. FEMS Microbiology Letters 78, 319-324.

BerG, K. L., Squires, C. \& Squires, C. L. (1989). Ribosomal RNA operon antitermination: function of leader and spacer region Box B-Box A sequences and their conservation in diverse microorganisms. Journal of Molecular Biology 209, 345-358.

Birendald, M., Schlessinger, D. \& Hashimoto, S. (1978). RNase III cleavage of Escherichia coli ribosomal RNA precursors: fragment release and dependence on salt concentration. Biochemistry 17, 298-307.

Birnboim, H. C. \& Doly, J. (1979). A rapid alkaline extraction procedure for screening recombinant plasmid DNA. Nucleic Acids Research 7, 1513-1523.

Bremer, H. \& DenNis, P. P. (1987). Modulation of chemical composition and other parameters of the cell by growth rate. In Escherichia coli and Salmonella typhimurium. Cellular and Molecular Biology, pp. 1527-1542. Edited by F. C. Neidhardt, J. L. Ingraham, K. Brooks-Low, B. Magasanik, M. Schaechter \& H. E. Umbarger. Washington, D.C.: American Society for Microbiology.

Brosius, J., Dull, T. J., Sleeter, D. D. \& Noller, H. F. (1981). Gene organisation and primary structure of a ribosomal RNA operon from Escherichia coli. Journal of Molecular Biology 148, 107-127.

BuRTon, K. (1957). Study of the conditions and mechanisms of the diphenylamine reaction for the colorimetric estimation of deoxyribonucleic acid. Biochemical Journal 62, 315-323.

CASHEL, M. \& RUdD, K.E. (1987). The stringent response. In Escherichia coli and Salmonella typhimurium:Cellular and Molecular Biology, pp. 1410-1438. Ediled by F. C. Neidhardt, J. L. Ingraham, K. Brooks-Low, B. Magasanik, M. Schaechter \& H. E. Umbarger. Washington, D.C.: American Society for Microbiology.

Collins, M. D., Ash, C., Farrow, J. A. E., Wallbanks, S. \& Williams, A. M. (1989). 16S ribosomal ribonucleic acid sequence analysis of lactococci and related taxa. Description of Vagococcus fluvialis gen. nov., sp. nov. Journal of Applied Bacteriology 67, $453-460$.

DaLY, C. (1983). The use of mesophilic cultures in the dairy industry. Antonie van Leeuwenhoek 49, 297-312.

Ellwood, M. \& Nomura. M. (1982). Chromosomal locations of the genes for rRNA in Escherichia coli K12. Journal of Bacteriology 149, $458-468$.

Gasson, M. J. (1983). Plasmid complement of Streptococcus lactis NCDO 712 and other streptococci after protoplast-induced curing. Journal of Bacteriology 1554, 1-9.

Gourse, R. L., DE BoER, H. A. \& Nomura, M. (1986). DNA determinants of ribosomal RNA synthesis in Escherichia coli: growth rate dependent regulation, feedback inhibition, up-stream activation, antitermination. Cell 44, 197-205.

Griswold, B. C., Humoller, F. L. \& McIntyre, A. R. (1951) Inorganic phosphates and phosphate esters in tissue extracts. Analytical Chemistry 23, 192-194.

HoLO, H. \& NES, I. F. (1989). High frequency transformation by electroporation of Lactococcus lactis subsp. cremoris growth with glycine in osmotically stabilized media. Applied and Environmental Microbiology 55, 3119-3123.

HORI, H. \& OSAWA, S. (1979). Evolutionary change in 5S rRNA secondary structure and a phylogenetic tree of 54 5S RNA species.
Proceedings of the National Academy of Sciences of the United States of America 76, 381-385.

INKS-ROBER TSON, S. \& NOMURA, M. (1987). Ribosomes and tRNA. In Escherichia coli and Salmonella typhimurium: Cellular and Molecular Biology, pp. 1358-1385. Edited by F. C. Neidhardt, J. L. Ingraham, K. Brooks-Low, B. Magasanik, M. Schaechter \& H. E. Umbarger. Washington, D.C.: American Society for Microbiology.

KING, T. C. \& SCHLFsINGER, D. (1987). Processing of RNA transcripts. In: Escherichia coli and Salmonella typhimurium: Cellular and Molecular Biology, pp. 703-708. Edited by F. C. Neidhardt, J. L. Ingraham, K. Brooks-Low, B. Magasanik, M. Schaechter \& H. E. Umbarger, Washington D.C.: American Society for Microbiology.

KoIvula, T., Sibukov, M. \& Palva, I. (1991). Isolation and characterisation of Lactococcus lactis subsp. lactis promoters. Applied and Environmental Microbiology 57, 333-340.

MANDEL, M. \& HIGA, A. (1970). Calcium-dependent bacteriophage DNA infection. Journal of Molecular Biology 53, 159-162.

Maniatis, T., Fritsch, E. F. \& Sambrook, J. (1982). Molecular Cloning. A Laboratory Manual. Cold Spring Harbor, NY: Cold Spring Harbor Laboratory Press.

MARShALL, V. M. E. \& LAW, B. A. (1984). The physiology and growth of dairy lactic acid bacteria. In Advances in the Microbiology and Biochemistry of Cheese and Fermented Milk, pp. 67-98. Edited by F. L. Davies \& B. A. Law, London: Elsevier Applied Science.

Mrller, J. H. (1972). Experiments in Molecular Genetics. Cold Spring Harbor, NY: Cold Spring Harbor Laboratory Press.

Neimark, H., Andersen, J. \& Delihas, N. (1983), Unusual structural features of the $5 \mathrm{~S}$ ribosomal RNA from Streptococcus cremoris. Nucleic Acids Research 11, 7569-7577.

NiERLICH, D. P. (1978). Regulation of bacterial growth, RNA and protein synthesis. Annual Reviews of Microbiology 32, 393 432.

Nomura, M., Gourse, R. L. \& Baughman, G. (1984). Regulation of the synthesis of ribosomes and ribosomal components. Annual Review of Biochemistry 53, 75-117.

Pernodet, J. L., Boccard, F., Alegre, M. T., Gagnat, J. \& GuerineaU, M. (1989). Organisation and nucleotide sequence analysis of a ribosomal RNA gene cluster from Streptomyces ambofaciens. Gene 79, 33-46.

ReITER, B. \& ORAM, J. D. (1962). Nutritional studies on cheese starters. I. Vitamin and amino acid requirements of single strain starters. Journal of Dairy Research 29, 63-77.

Ross, W., Thompson, J. F., Newlands, J. T. \& Gourse, K. L. (1990). $E$. coli FIS protein activates ribosomal RNA transcription in vitro and in vivo. EMBO Journal 9, 3733-3742.

SANGer, F., Nicklen, S. \& Coulson, A. R. (1977). DNA sequencing with chain-terminating inhibitors. Proceedings of the National Academy of Sciences of the United States of America 74, 5463-5467.

SARMIENTOS, P. \& CASHEL, M. (1983). Carbon starvation and growth rate dependent regulation of the Escherichia coli ribosomal RNA promoters: differential control of dual promoters. Proceedings of the National Academy of Sciences of the United States of America 80, $7010-7013$.

Schaechter, M., Maalge, O. \& KJeldgatid, N. O. (1958). Dependency on medium and temperature of cell size and chemical composition during balanced growth of Salmonella typhimurium. Journal of General Microbiology 19, 592-606.

Schleifer, K. H., Kraus, J., Dvorak, C., Killpper-Balz, R., Collins, M. D. \& FisCHER, W. (1985). Transfer of Streptococcus lactis and related streptococci to the genus Lactococcus gen. nov. Systematic and Applied Microbiology 6, 183-195.

SHAW, W. V. (1975). Chloramphenicol acetyltransferase from chloramphenicol-resistant bacteria. Methods in Enzymology 43, $737-755$.

Spaink, H. P., Okker, R. J. H., WiJfFelman, C. A., Peer, E. \& LUTENBERG, B. J. J. (1987). Promoters in the nodulation region of Rhizobium leguminosarum sym plasmid pRL1J1. Plant Molecular Biology 9, 27-39.

StaCKEbrandi, E. \& Teuber, M. (1988). Molecular taxonomy and phylogenetic position of lactic acid bacteria. Biochimie 70, 317-324.

STENT, G. S. \& BRENNER, S. (1961). A genetic locus for the regulation of ribonucleic acid synthesis. Proceedings of the National Academy of Sciences of the United States of America 49, 2005-2014. 
Terzaghi, B. E. \& SANDINE, W. E. (1975). Improved medium for lactic streptococci and their bacteriophages. Applied Microbiology 29, 809-813.

Thomas, T. D., Ellwood, D. C. \& Longyear, V. M. C. (1979). Change from homo- to heterolactic fermentation by Streptococcus lactis resulting from glucose limitation in anaerobic chemostat cultures. Journal of Bacteriology 138, 109-117.

DE VOS, W. M. (1987). Gene cloning and expression in the lactic streptococci. FEMS Microbiology Reviews 46, 281-295.
Van Der Vossen, J. M. B. M., KoK, J. \& Venema, G. (1985). Construction of cloning, promoter-screening and terminator-screening shuttle vectors for Bacillus subtilis and Streptococcus lactis. Applied and Environmental Microbiology 50, 540-542.

YouNG, R. A. (1979). Transcription termination in Escherichia coli ribosomal RNA operon $r m$ C. Journal of Biological Chemistry 254, 12725-12731.

YounG, R. A. \& STEITZ, J. A. (1979). Tandem promoters direct E. coli ribosomal RNA synthesis. Cell 17, 225-234. 